\title{
KONDISI SOSIAL EKONOMI KELUARGA NELAYAN DAN PENGARUHNYA TERHADAP TINGKAT PENDIDIKAN ANAK DI DESA BULAWAN INDUK KECAMATAN KOTABUNAN KABUPATEN BOLAANG MOGONDOW TIMUR
}

\author{
Indra Moha'; Srie J. Sondakh2; Olvie V. Kotambunan² \\ 1)Mahasiswa Fakultas Perikanan dan IImu Kelautan Universitas Sam Ratulangi Manado \\ 2) Staff Pengajar Fakultas Perikanan dan IImu Kelautan Universitas Sam Ratulangi Manado \\ Koresponden email : mohaindra23@gmail.com
}

\begin{abstract}
The purpose of this study was to describe and explain the socio-economic conditions of fisherman families in Bulawan Induk Village towards the level of education of children. The method used in this study was a case study, and the population in this study were parents of families of fishermen who had children while in school. Sampling using puroposive sampling technique, which takes 25 people or $20 \%$ of the 121 population in the study location. Bulawan Induk Village, Kotabunan Subdistrict, Bolaang Mongondow Timur Regency has a population of approximately 1,167 people, 613 men and 554 women with 309 families. Bulawan Induk village has a variety of tribes, among others: Mongondow, Gorontalo, Sanger and Minahasa. The social conditions of fishermen in Bulawan Induk Village are very influential in terms of education, most of them are elementary schooled, there are 2 respondent religions namely Islam and Protestant Christianity, the age of fishermen is in the productive age range of 8 people, most dependents are on average 1 - 5 the majority of people per family and home conditions (44\%) respondents have a type of house from the board.
\end{abstract}

Key Words: Socio-economic, fisherman family, children education level, Bulawan Induk Village

\begin{abstract}
Abstrak
Tujuan penelitian ini adalah untuk mendeskripsikan dan menjelaskan keadaan sosial ekonomi keluarga nelayan di Desa Bulawan Induk terhadap tingkat pendidikan anak. Metode digunakan dalam penelitian ini adalah studi kasus, dan yang menjadi populasi dalam penelitian ini adalah orang tua dari keluarga nelayan yang memiliki anak sedang sekolah. Pengambilan sampel menggunakan teknik puroposive sampling, yaitu mengambil 25 orang atau $20 \%$ dari 121 populasi yang ada di lokasi penelitian. Desa Bulawan Induk Kecamatan Kotabunan, Kabupaten Bolaang Mongondow Timur memiliki jumlah penduduk kurang lebih 1.167 jiwa, laki-laki 613 jiwa dan perempuan 554 jiwa dengan 309 Kepala Keluarga. Desa Bulawan Induk terdapat beragam suku antara lain: suku Mongondow, Gorontalo, Sanger dan Minahasa. Kondisi sosial nelayan di Desa Bulawan Induk sangat berpengaruh dilihat dari segi pendidikan paling banyak berpendidikan SD, terdapat 2 agama responden yaitu Islam dan Kristen Protestan, umur nelayan berada pada kisaran umur produktif sebanyak 8 orang, sebagian besar responden tanggungan keluarga rata - rata 1 - 5 orang per kepala keluarga dan kodisi rumah sebagian besar (44\%) responden memiliki jenis rumah dari papan/triplex.
\end{abstract}

Kata Kunci: Sosial ekonomi, keluarga nelayan, tingkat pendidikan anak, Bulawan Induk.

\section{PENDAHULUAN}

Seiring dengan maju dan berkembangnya IImu Pengetahuan dan Teknologi, kebutuhan manusiapun semakin banyak dan berkembang pula. Pendidikan mulai menjadi kebutuhan primer bagi masyarakat. Hal ini sesuai dengan amanat UUD 1945 Pasal 31 ayat 1, yaitu "setiap warga negara berhak mendapat pendidikan sehingga pemerintah wajib mengusahakan dan menyelenggarakan pendidikan nasional karena pendidikan merupakan tiang dan pondasi terpenting dalam kehidupan guna mewujudkan masa depan bangsa yang cemerlang.

Kondisi masyarakat nelayan atau masyarakat pesisir diberbagai kawasan pada umumnya ditandai oleh adanya beberapa ciri, seperti kemiskinan, keterbelakangan sosial-budaya, rendahnya sumberdaya manusia, sehingga pada saat ini dapat dilihat bahwa sebagian besar masyarakat pesisir masih berada dibawah garis kemiskinan (Nasution 2005).

Kabupaten Bolaang Mongondow Timur memiliki panjang garis pantai $122,878 \mathrm{~km}^{2}$ dengan batas teritorial 
$78,975 \mathrm{~km}^{2}$ dan ZEE $365,000 \mathrm{~km}^{2}$, juga memiliki 6 buah danau dan 6 buah pulau. Potensi ikan yang dapat dimanfaatkan di perairan laut teritorial berjumlah 1.225.034 ton/tahun sedangkan di perairan ZEE 1.437.195 ton/tahun. Potensi ini meliputi ikan demersal dan ikan pelagis. Pada tahun 2016 memiliki produksi di bidang perikanan sebesar 1.166 .993 ton dan pada tahun 2017 memiliki produksi sebesar 1.225.034 ton. (Dinas Perikanan 2017)

Masyarakat nelayan merupakan salah satu bagian masyarakat yang hidup dengan mengelola potensi sumberdaya perikanan. Sebagai suatu masyarakat yang tinggal di kawasan pesisir, masyarakat nelayan mempunyai karakteristik sosial tersendiri yang berbeda dengan masyarakat lainnya yang tinggal di wilayah daratan. Karakteristik yang menjadi ciri-ciri sosial budaya masyarakat nelayan adalah memiliki struktur relasi patron-klien sangat kuat, etos kerja tinggi, memanfaatkan kemampuan diri dan adaptasi optimal, kompetitif dan berorientasi prestasi, apresiatifferhadap keahlian, kekayaan dan kesuksesan hidup, terbuka dan ekpresif, solidaritas sosial tinggi, sistem pembagian kerja yang unik antara laki-laki dan perempuan dimana laut menjadi ranah laki-laki dan darat adalah ranah kaum perempuan, dan berperilaku konsumtif (Kusnadi 2009).

Masyarakat nelayan menghadapi sejumlah masalah politik, sosial dan ekonomi yang komplek. Hal ini disebabkan oleh kebijakan pembangunan yang belum bersungguhsungguh, persoalan sosial ekonomi yang terjadi pada masyarakat nelayan cukup kompleks, sehingga penyelesaiannya tidak seperti membalikkan telapak tangan. Pada hal nelayan merupakan pelaku utama pembangunan, sehingga diperlukan kualitas sumberdaya manusia yang potensial, untuk menuju cita-cita rakyat Indonesia, yaitu bangsa yang makmur dan berkepribadian luhur, terlebih lagi dizaman yang semakin modern, masyarakat dituntut untuk mempunyai ketrampilan atau kompetensi dalam dirinya sendiri. Menurut (Kusnadi 2009).

Desa Bulawan Induk merupakan desa pesisir yang ada di Kecamatan Kotabunan Kabupaten Bolaang Mongondow Timur dengan jumlah penduduk 1.167 jiwa terdiri dari laki-laki 554 jiwa, perempuan 613 jiwa dan memiliki 309 kepala keluarga. Sebagian besar masyarakatnya berprofesi sebagai nelayan kurang lebih 121 jiwa namun dalam hal pendidikan bila dibandingkan dengan daerah lainnya yang ada di Provinsi Sulawesi Utara masih jauh tertinggal, apalagi bila dilihat dari minat anak usia sekolah untuk mengenyam pendidikan pada sekolah formal selalu terhalang kondisi biaya sehingga anak lebih memilih untuk membantu orang tua dalam mencukupkan kebutuhan setiap hari-harinya, maka dilakukan penelitian tentang kondisi sosial ekonomi keluarga nelayan dan pengaruhnya bagi tingkat pendidikan anak di Desa Bulawan Induk Kecamatan Kotabunan Kabupaten Bolaang Mongondow Timur.

\section{METODE PENELITIAN}

Jenis penelitian yang digunakan adalah studi kasus, ialah suatu rangkaian kegiatan ilmiah yang dilakukan secara intensif, terinci dan mendalam tentang suatu progaram, peristiwa, dan aktivitas, baik pada tingkat perorangan, sekolompok orang, lembaga atau organisasi untuk memperoleh pengetahuan mendalam tentang 
peristiwa tersebut. Penelitian ini bersifat deskriptif eksploratif, yang bertujuan menggambarkan atau memaparkan sesuatu hal misalnya keadaan, kondisi, situasi, peristiwa, kegiatan dan lain-lain.

Pengambilan sampel menggunakan teknik puroposive sampling. Purposive sampling adalah suatu cara pengumpulan data yang sifatnya tidak menyeluruh, yaitu tidak mencakup seluruh objek penelitian (populasi) akan tetapi sebagian saja dari populasi (Sugiyono 2014). Adapun yang menjadi populasi dalam penelitian ini adalah keluarga nelayan yang memiliki anak sedang sekolah, di Desa Bulawan Induk Kecamatan Kotabunan yang berjumlah kurang lebih 121 Kepala Keluarga. Selanjutnya yang menjadi responden adalah kurang lebih 25 keluarga nelayan yang mempunyai anak sedang sekolah dalam keluarganya.

Teknik pengumpulan data dalam penelitian ini dengan menggunakan kuesioner atau daftar pertanyaan untuk memperoleh informasi dari rersponden dalam arti laporan tentang pribadinya, atau hal-hal yang diketahui oleh responden. Angket adalah teknik pengumpulan data yang dilakukan dengan cara memberikan pertanyaan atau pernyataan tertulis kepada responden untuk dijawabnya (Sugiyono 2014). Teknik pengumpulan data juga menggunakan wawancara adalah percakapan dengan maksud tertentu. Percakapan yang dilakukan oleh dua pihak yaitu pewawancara yang mengajukan pertanyaan dan terwawancara yang memberikan jawaban atas pertanyaan tersebut (Maleong 2006). Metode ini dilakukan pada saat melakukan pengumpulan data dan untuk mendapatkan data yang diperlukan peneliti sehingga bisa menjawab rumusan masalah penelitian.

\section{HASIL DAN PEMBAHASAN \\ Kondisi Sosial Keluarga Nelayan \\ Pendidikan Formal Ayah}

Tabel 1. Tingkat Pendidikan Formal Ayah

\begin{tabular}{|c|l|c|c|}
\hline No & Pendidikan Tertinggi & Jumlah & $\begin{array}{c}\text { Persentase } \\
(\%)\end{array}$ \\
\hline 1 & SD & 16 & 64 \\
\hline 2 & SLTP & 7 & 28 \\
\hline 3 & SLTA & 2 & 8 \\
\hline 4 & Sarjana & 0 & 0 \\
\hline \multicolumn{2}{|r|}{ Jumlah } & 25 & 100 \\
\hline
\end{tabular}

Sumber: Data Primer, 2018

Berdasarkan Tabel 1, menunjukkan bahwa jumlah terbesar terhadap tingkat pendidikan formal ayah paling banyak berada pada tingkat SD sebanyak 16 responden (64\%), selanjutnya pada tingkat SLTP/Tamat SLTP dengan jumlah 7 responden (28), dan ditingkat SLTA/Tamat SLTA hanya 2 responden $(8 \%)$. Pendidikan ayah hanya SD dikarenakan pada jamannya mereka, ternyata para nelayan lebih tertarik ikut orang tua melaut dari pada ke sekolah, dan masih tertanam anggpan bahwa jika sudah tahu membaca dan menulis tidak perlu sekolah tinggi - tinggi walaupun fasilitas sekolah tersedia.

\section{Pendidikan Formal Ibu}

Tabel 2. Tingkat Pendidikan Formal lbu

\begin{tabular}{|c|l|c|c|}
\hline No & Pendidikan Tertinggi & Jumlah & $\begin{array}{c}\text { Persentase } \\
(\%)\end{array}$ \\
\hline 1 & SD & 20 & 80 \\
\hline 2 & SLTP & 4 & 16 \\
\hline 3 & SLTA & 1 & 4 \\
\hline 4 & Sarjana & 0 & 0 \\
\hline \multicolumn{2}{|c|}{ Jumlah } & 25 & 100 \\
\hline
\end{tabular}

Sumber: Data Primer, 2018

\section{Berdasarkan Tabel 2,} menunjukkan untuk tingkat pendidikan formal lbu pada tingkat SLTA/Tamat SLTA hanya sebanyak 1 responden (4\%), selanjutnta ditingkat SLTP/Tamat SLTP sebanyak 4 responden (16\%) dan pada tingkat SD/Tamat SD sebanyak 20 responden $(80 \%)$. Jadi bisa disimpulkan bahwa hasil terbesar ada pada tingkat 
pendidikan SD yaitu sebanyak 20 responden (80\%). Hal ini terjadi karena kurang perhatian orang tua terdahulu untuk menyekolahkan anak - anak karena terhalangi faktor ekonomi yang sangat lemah, dan kurangnya minat anak untuk sekolah ke tingkat yang lebih tinggi dikarenakan mereka lebih melilih untuk nikah muda dengan beraggapan dapat mengurangi beban orang tua agar dapat memenuhi kebutuhan hidup keluarga.

\section{Pendidikan Anak}

Tabel 3. Tingkat Pendidikan Anak Responden

\begin{tabular}{|c|l|c|c|}
\hline No & \multicolumn{1}{|c|}{$\begin{array}{c}\text { Pendidikan } \\
\text { Tertinggi }\end{array}$} & Frekuensi & $\begin{array}{c}\text { Persentase } \\
\text { (\%) }\end{array}$ \\
\hline 1 & SD & 9 & 26 \\
\hline 2 & SLTP & 14 & 41 \\
\hline 3 & SLTA & 7 & 21 \\
\hline 4 & PT & 4 & 12 \\
\hline \multicolumn{2}{|c|}{ Jumlah } & 25 & 100 \\
\hline
\end{tabular}

Sumber: Data Primer, 2018

Pada Tabel di atas menggambarkan bahwa tingkat pendidikan anak responden sedang di tingkat SD $26(\%)$, sedang SLTP $(41 \%)$, diikuti SLTA (21\%) dan Perguruan Tinggi (12\%). Hal ini disebabkan karena salah satu program pemerintah yakni mewajibkan 9 tahun belajar. Artinya anak-anak diseluruh Indonesia diberikan pendidikan secara gratis pada tingkatan SD dan SLTP, akan tetapi anak-anak nelayan Desa Bulawan Induk belum dapat memanfaatkan kesempatan yang disediakan oleh pemerintah.

Walaupun pendidikan orang tua rata-rata tidak tamat SD, namun keinginan orang tua untuk menyekolahkan anak kejenjang yang lebih tinggi tetap ada, sehingga ada 4 anak $(12 \%)$ keluarga nelayan sementara duduk di jenjang perguruan tinggi dan malah ada yang sudah menyelesaikan pendidikannya.

\section{Tanggungan Keluarga}

Rumah tangga yang dikepalai oleh seorang kepala keluarga dengan pendidikan rendah cenderung lebih miskin dibandingkan dengan rumah tangga yang dikepalai oleh mereka yang berpendidikan tinggi. Banyaknya jumlah anggota keluarga rata-rata ( 1 - 5 orang) akan mempengaruhi tinggi rendahnya pendapatan per kapita serta besarnya konsumsi keluarga. Oleh karena itu, jumlah anggota keluarga akan memberi dorongan bagi rumah tangga bersangkutan untuk lebih banyak menggali sumber pendapatan lainnya.

Besarnya beban tanggungan keluarga pada 25 responden di Bulawan Induk akan berpengaruh terhadap tingkat kebutuhan dan kesejahteraan mereka, semakin banyak tanggungan keluarga maka semakin banyak pula kebutuhan rumah tangga yang harus dipenuhi. Jika pendapatan dari profesi sebagai nelayan tidak mampu mencukupi kebutuhannya maka akan berdampak pada masalah kesejahteraan dalam keluarga. Di bawah ini dapat dilihat tabel tanggungan keluarga nelayan di Desa Bulawan Induk.

Tabel 4. Jumlah Responden Berdasarkan Tanggungan Keluarga

\begin{tabular}{|c|l|c|c|}
\hline No & $\begin{array}{c}\text { Jumlah } \\
\text { Tanggungan }\end{array}$ & $\begin{array}{c}\text { Jumlah } \\
\text { Orang }\end{array}$ & $\begin{array}{c}\text { Persentase } \\
(\%)\end{array}$ \\
\hline 1 & $1-3$ & 2 & 8 \\
\hline 2 & $4-6$ & 21 & 84 \\
\hline 3 & $7-9$ & 2 & 8 \\
\hline \multicolumn{2}{r|}{ Total } & 25 & 100 \\
\hline
\end{tabular}

Sumber: Data Primer, 2018

Berdasarkan hasil penelitian pada tabel diatas tentang jumlah tanggungan keluarga di desa Bulawan Induk yaitu jumlah tanggungan 1 - 3 orang dalam 1 keluarga terdapat 2 responden $(8 \%)$, jumlah tanggungan 4 - 6 orang dalam 1 keluarga terdapat 21 responden dan jumlah tanggungan 7 - 9 orang dalam 1 keluarga terdapat 2 responden. 


\section{Perumahan}

Kondisi rumah penduduk nelayan Desa Bulawan Induk masih tergolong sederhana. Hanya ada beberapa responden memiliki kondisi rumah yang layak tinggal seperti rumah permanen sedangkan responden lainnya, bangunan rumah menggunakan tripleks/bambu sebagai dinding rumah. Keadaan rumah seperti itu kebanyakan berada pesisir pantai atau tepatnya di Dusun I. Informasi dari masyarakat setempat bahwa tanah yang mereka tempati adalah milik sendiri yang di dapat dari hasil warisan keluarga. Jenis rumah responden dapat dilihat pada Tabel 5.

Tabel 5. Jumlah Responden Berdasarkan Kepemilikan Rumah

\begin{tabular}{|c|l|c|c|}
\hline No & \multicolumn{1}{|c|}{ Jenis Rumah } & Jumlah & $\begin{array}{c}\text { Persentase } \\
(\%)\end{array}$ \\
\hline 1 & Permanen /Beton & 2 & 8 \\
\hline 2 & Semi Permanen & 10 & 40 \\
\hline 3 & Gubuk/Bambu & 2 & 8 \\
\hline 4 & Papan/Triplex & 11 & 44 \\
\hline \multicolumn{2}{|c|}{ Jumlah } & 25 & 100 \\
\hline
\end{tabular}

Sumber: Data Primer, 2018

Berdasarkan Tabel di atas hasil penelitian didapatkan responden yang paling banyak mempunyai rumah papan/triplex 11 responden (44\%), dan responden yang mempunyai Rumah semi permanen 10 respoden atau (40\%), sedangkan responden yang tinggal di pesisir pantai Desa Bulawan Induk di lingkungan Dusun I ada 2 reponden dan tinggal di rumah gubuk/bambu. Dari hasil penelitian didapati ada Keluarga Nelayan yang tinggal di kawasan milik Pemerintah setempat ada 6 kepala keluarga termasuk di lingkungan Dusun I.

\section{Kondisi Ekonomi Responden di Desa Bulawan Induk}

\section{Modal}

Modal usaha yang dikeluarkan nelayan di Desa Bulawan Induk dalam menjalankan operasi penangkapan dapat dilihat pada Tabel 6 .

Tabel 6. Jumlah Responden Berdasarkan Modal Usaha Penangkapan.

\begin{tabular}{|c|l|c|c|}
\hline No & \multicolumn{1}{|c|}{ Modal Usaha } & Jumlah & $\begin{array}{c}\text { Persentase } \\
(\%)\end{array}$ \\
\hline 1 & Modal sendiri & 19 & 76 \\
\hline 2 & Modal pinjaman & 4 & 16 \\
\hline 3 & Bantuan Pemerintah & 2 & 8 \\
\hline \multicolumn{2}{|c|}{ Jumlah } & 25 & 100 \\
\hline
\end{tabular}

Sumber: Data Primer, 2018

Pada Tabel di atas modal yang digunakan pada produksi nelayan terdiri atas biaya perawatan dan biaya pengeluaran produksi. Semakin besar modal yang digunakan, maka akan semakin besar pula hasil produksi nelayan menurut (Rahman 2006). Tabel ini menggambarkan bahwa keluarga nelayan yang menjadi responden mempunyai modal usaha sendiri terdapat 19 orang (76\%) dengan jumlah biaya yang dikeluarkan untuk modal tersebut sebesar Rp 500.000 - Rp 2.000.000. Modal usaha pinjaman terdapat 4 orang $(16 \%)$ dengan jumlah biaya pinjaman $R p$ 2.000.000 - Rp 4.000.000. Sedangkan modal bantuan pemerintah hanya 2 orang $(8 \%)$ karena nelayan tersebut memasukan proposal ke Kantor Dinas Kelautan dan Perikanan Kabupaten Bolaang Mongondow Timur dan hasilnya bukan berupa uang tunai melainkan jenis bantuan berupa Motor Katinting 6,5 PK dan perahu pelang.

\section{Tingkat Pendapatan}

Nelayan yang berada di Desa Bulawan Induk umumnya adalah nelayan tradisional yang usaha penangkapannnya masih menggunakan perahu dan alat tangkap tradisional. Selain itu jangkauan wilayah operasi penangkapan para nelayan di Desa Bulawan Induk hanya di sekitar perairan Laut Maluku saja. Rincian tingkat pendapatan nelayan perbulannya di 
Desa Bulawan Induk disajikan pada Tabel dibawah ini.

Tabel 7. Rata-rata Pendapatan Utama Responden per Bulan.

\begin{tabular}{|c|l|c|c|}
\hline No & \multicolumn{1}{|c|}{$\begin{array}{c}\text { Tingkat Pendapatan } \\
(\mathrm{Rp})\end{array}$} & Jumlah & $\begin{array}{c}\text { Persentase } \\
(\%)\end{array}$ \\
\hline 1 & $\begin{array}{l}\operatorname{Rp~} 500.000- \\
\operatorname{Rp~} 1.000 .000\end{array}$ & 5 & 20 \\
\hline 2 & $\begin{array}{l}\operatorname{Rp~} 1.000 .000- \\
\operatorname{Rp~} 2.000 .000\end{array}$ & 6 & 24 \\
\hline 3 & $\begin{array}{l}\operatorname{Rp~} 2.000 .000- \\
\operatorname{Rp~3.000.000~}\end{array}$ & 11 & 44 \\
\hline 4 & $>$ Rp 3.000.000 & 3 & 12 \\
\hline \multicolumn{2}{|c|}{ Jumlah } & 25 & 100 \\
\hline
\end{tabular}

Sumber: Data Primer, 2018

Pada tabel diatas menunjukan bahwa pendapatan nelayan yang paling rendah berkisar $\mathrm{Rp} 500.000$ - Rp 1.000.000 per bulan berjumlah 5 responden (20\%), untuk pendapatan yang $R p 1.000 .000$ - Rp 2.000.000 ada 6 responden (24\%), sedangkan pendapatan $\mathrm{Rp} 2.000 .000$ - Rp 3.000 .000 didapati 11 responden (44\%), dan sisanya 3 responden (12\%), memiliki pendapatan lebih dari $\mathrm{Rp}$ 3.000.000.

\section{Tingkat Pengeluaran}

Profesi sebagai nelayan sangatlah tidak gampang karena tuntutan biaya pengeluaran yang besar. Penelitian terhadap 25 responden dimana pengeluaran per bulan untuk satu keluarga rata-rata berjumlah $\mathrm{Rp}$ 1.000.000 - Rp 3.000.000. Tingkat pengeluaran pada setiap nelayan yang menjadi responden tentu berbeda, ada yang mempunyai kebutuhan lebih banyak untuk keluarganya dan juga keluarga yang kebutuhannya sedikit. Hal ini tergantung pada jumlah tanggungan keluarganya, pengeluaran responden dalam satu bulan dapat dilihat pada Tabel 8.
Tabel 8. Jumlah Tingkat Pengeluaran Responden per Bulan

\begin{tabular}{|c|c|c|c|}
\hline No & $\begin{array}{c}\text { Tingkat Pengeluaran } \\
\text { (Rp) }\end{array}$ & Jumlah & $(\%)$ \\
\hline 1 & Rp. 500.000 - Rp 1.000 .000 & 8 & 32 \\
\hline 2 & $\operatorname{Rp} 1.000 .000-\operatorname{Rp} 2.000 .000$ & 6 & 24 \\
\hline 3 & Rp. $2.000 .000-\operatorname{Rp} 3.000 .000$ & 8 & 32 \\
\hline 4. & $>$ Rp. 3.000 .000 & 3 & 12 \\
\hline & Jumlah & 25 & 100 \\
\hline
\end{tabular}

Sumber: Data Primer, 2018

Berdasarkan hasil penelitian dapat dilihat pada tabel 12, tingkat pengeluaran mulai dari $\operatorname{Rp} 500.000$ Rp 1.000 .000 berjumlah 8 orang (32\%), selanjutnya pengeluaran responden $\mathrm{Rp}$ 1.000 .000 - Rp 2.000.000 berjumlah 6 orang (24\%), dan pengeluaran responden Rp. 2.000.000 - Rp 3.000 .000 berjumlah 8 orang (32\%), yang terakhir jumlah pengeluaran lebih dari $\mathrm{Rp} 3.000 .000$ berjumlah 3 orang $(12 \%)$.

Besar kecilnya pengeluaran disebabkan besarnya ongkos atau harga yang harus dibayarkan untuk biaya makanan, pakaian, kesehatan, perumahan, listrik, transportasi dan lainnya sehingga biaya untuk pendidikan anak akan ikut berpengaruh yang mengakibatkan orang tua bahkan kadang pasarah trehadap kondisi anak yang tidak melanjutkjan sekolahnya sehingga sangat dibutuhkan berbagai masukan tentang pentingnya pendidikan bagi keluarga nelayan lewat pemerintah yang ada. Ada juga nelayan yang mengeluarkan biaya lebih dari $\mathrm{Rp}$. 3.000.000 per bulan karena menyekolahkan anak sampai Perguruan Tinggi. Hal ini terjadi pada nelayan yang memiliki pekerjaan sampingan sebagai nelayan perahu lampu dan ada yang berstatus Kepala Dusun.

\section{Pengaruh Kondisi Sosial Ekonomi Keluarga Neayan Terhadap Tingkat Pendidikan Anak.}

Kondisi sosial ekonomi dalam penelitian ini berkaitan dengan tingkat 
pendidikan anak keluarga nelayan yang tentunya bergantung pada tingkat pendapatan keluarga nelayan itu sendiri tapi juga posisi seseorang dalam kelompok masyarakat di tentukan oleh berbagai jenis aktivitas masyarakat berkaitan erat dengan berbagai aktivitas sosial ekonomi lainnya, antara lain dengan pendidikan orang tua, agama, umur, tanggungan keluarga, perumahan, modal, pendapatan, dan pengeluaran keluarga nelayan.

\section{Pengaruh Pendidikan Orang Tua Terhadap Tingkat Pendidikan Anak}

Tinggi rendahnya tingkat pendidikan anak dipengaruhi oleh pendidikan orang tuanya, dimana bila tingkat pendidikan yang rendah, mereka cenderung kurang memiliki perhatian tentang pentingnya pendidikan bagi anak-anaknya. Hasil penelitian di ketahui bahwa latar belakang pendidikan orang tua pada keluarga nelayan rata-rata tidak lulus pendidikan dasar (SD) dengan persentase $64 \%$ untuk suami dan $80 \%$ untuk istri, sedangkan yang memiliki latar belakang pendidikane Sekolah Menengah Atas (SMA) hanya 8\% suami, dan $4 \%$ istri. Dengan kondisi seperti ini maka dapat dikatakan wawasan atau kesadaran keluarga nelayan tentang dunia pendidikan sangat kurang walaupun tidak menutup kemungkinan ada yang mempunyai wawasan atau kesadaran tinggi tentang pendidikan. Sehingga sangat di butuhkan berbagai masukan tentang pentingnya pendidikan bagi keluarga nelayan, lewat pemerintah yang ada.

\section{Pengaruh Agama Orang Tua Terhadap Tingkat Pendidikan Anak}

Pentingnya agama dalam

kehidupan umat manusia sangat berpengaruh dalam banyak aspek, antara lain memberikan tuntunan berupa aturan menghidupkan nilai luhur moralitas tapi juga mendukung nilai keadilan, kejujuran, toleransi dan tolong menolong. Semuanya ini menjadi kekuatan atau pendorong yang memotivasi manusia dalam keberaturan, sehingga tidak merugikan orang lain maupun lingkungan sekitar, tapi mampu mengenal hal baik dan buruk, sebagai penyeimbang jiwa. Pada tabel 06 memberikan informasi bahwa ada 23 responden (92\%) di Desa Bulawan Induk beragama Islam, di ikuti oleh Kristen protestan dan Katolik masing-masing 1 responden, sehingga bisa dikatakan bahwa sebagian besar masyarakatnya menganut agama Muslim. Pendidikan agama dalam keluarga sangat penting, sebab apa yang terjadi dalam lingkungan tersebut akan membawa pengaruh yang sangat besar terhadap anak, baik di sekolah maupun di lingkungan masyarakat.

\section{Pengaruh Umur Orang tua Terhadap Tingkat Pendidikan Anak}

Dari hasil analisis tentang umur atau usia orang tua, mayoritas berusia kurang dari 50 tahun dengan persentasi sebesar $36 \%$, sedangkan yang berusia lebih dari 32 tahun hanya 6\%, Gambaran umur nelayan di Desa Bulawan Induk sebagaimana Undang-Undang Tenaga Kerja No. 13 Tahun 2003 dan menurut Badan Pusat Statistik, tergolong umur produktif karena mereka termasuk dalam golongan usia 15 - 64 tahun. Umur produktif berarti nelayan tersebut masih kuat dan bersemangat dalam melaut, sehingga diharapkan dengan usia yang produktif ini para nelayan bisa memperoleh hasil produksi yang tinggi dan padsa akhirnya memperoleh pendapat yang tinggi pula bila harga ikan baik. Sehingga dengan pendapatan yang layak, mereka mampu menyekolahkan anak-anaknya. 


\section{Pengaruh Tanggungan Keluarga Nelayan Terhadap Tingkat Pendidikan Anak}

Berdasarkan hasil penelitian tentang jumlah tanggungan keluarga di Desa Bulawan Induk yaitu jumlah tanggungan 8 orang terdapat 1 keluarga dan yang sedikit atau 3 orang terdapat 2 keluarga atau sebanyak $8 \%$. Menurut hasil wawancara dengan responden menjadi kepala keluarga tentu harus bekerja keras untuk memenuhi kebutuhan keluarganya. Sebanyak $84 \%$ dengan tanggungan keluarga $4-6$ orang. Sehubungan dengan pendidikan anak dikemudian hari, bisa dikatakan bahwa dengan tanggungan keluarga yang sedikit, sebenarnya peluang untuk menyekolahkan anak semakin tinggi. Pendapatan yang diperoleh kepala keluarga bisa membiayai semua anak usia sekolah. Di Desa Bulawan Induk, dengan tanggungan keluarga yang tinggi menyebabkan anak yang mengalah dan tidak bersekolah karena menurut orang tuanya yang sulung cukup sampai SD atau SMP dan berikutnya giliran anak yang nomor dua dan begitu seterusnya. Makanya tanggungan keluarga masih merupakan salah satu faktor permasalahan kurangnya pendidikan sampai SMA bagi nelayan di Desa Bulawan Induk.

\section{Pengaruh Perumahan Tingkat Pendidikan Anak}

\section{Terhadap}

Hasil penelitian didapatkan responden yang paling banyak mempunyai rumah papan/triplex 11 responden (44\%), dan masyarakat yang mempunyai Rumah semi permanen 10 respoden atau (40\%), sedangkan masyarakat nelayan yang tinggal di pesisir pantai Desa Bulawan Induk di lingkungan Dusun I ada 2 reponden dan tinggal di rumah gubuk/bambu. Dari hasil penelitian didapati ada Keluarga Nelayan yang tinggal di kawasan milik Pemerintah setempat ada $6 \mathrm{KK}$ termasuk di lingkungan Dusun I hal ini sangat berpengaruh terhadap tingkat pendidikan anak karena orang tua masih menyampingkan pendidikan anak - anak meraka, dari penjelasan diatas tentang kepemilikan rumah di Desa Bulawan tentunya menjadi salah satu penyebab sehingga pendidikan anak masih terabaikan.

\section{Pengaruh Modal Terhadap Tingkat Pendidikan Anak}

Modal yang digunakan pada produksi nelayan terdiris atas biaya perawatan dan biaya pengeluaran produksi. Semakin besar modal yang digunakan, maka akan semakin besar pula hasil produksi nelayan (Rahman 2006). Tabel 10 menggambarkan bahwa keluarga nelayan yang menjadi responden mempunyai modal usaha sendiri terdapat 19 orang $(76 \%)$ dengan jumlah biaya yang dikeluarkan untuk modal tersebut sebesar Rp 500.000 Rp 2.000.000. Modal usaha pinjaman terdapat 4 orang $(16 \%)$ dengan jumlah biaya pinjaman $\mathrm{Rp} 2.000 .000$ - Rp 4.000.000. Sedangkan modal bantuan pemerintah hanya 2 orang (8\%) karena nelayan tersebut memasukan proposal ke Kantor Dinas Kelautan dan Perikanan Kabupaten Bolaang Mongondow Timur dan hasilnya bukan berupa uang tunai melainkan jenis bantuan berupa Motor Katinting 6,5 PK dan perahu pelang. Dari hasil penelitian di dapati 4 responden yang masih menminjam modal untuk biaya operasi penangkapan oleh nelayan responden mengakibatkan ada nelayan masih memikirkan biaya untuk mengembalikan pinjaman tapi juga nelayan lainnya memfokuskan ingin memperbesar modal dari pada memotivasi anak untuk sekolah. 


\section{Pengaruh Pendapatan Keluarga Nelayan Terhadap Tingkat Pendidikan Anak}

Dilihat dari tingkat pendapatan keluarga, dengan jumlah penghasilan berkisar antara Rp. 500.000 hingga Rp 3.000 .000 , kemudian setiap keluarga memiliki 4 orang tanggungan, maka jelas terlihat jumlah penghasilan hanya akan habis digunakan untuk kebutuhan makan dan kebutuhan keluarga lainnya diluar pendidikan. Hasil wawancara dengan keluarga nelayan yang menjadi responden bahwa hampir semua tidak memiliki tabungan dan kalaupun ada hanya disiapkan untuk membeli perlengkapan melaut pada hari berikutnya, sehingga budaya menabung belum menjadi suatu kebiasaan bagi keluarga nelayan responden.

Disamping itu juga pendapatan dari pekerjaan sambilan hanya didapati 3 orang nelayan, yaitu 2 orang sebagai pemilik perahu lampu dan 1 orang sebagai Kepala Dusun, dan mereka mempunyai pendapatan $\operatorname{Rp~500,000~-~}$ Rp 2.000.000 per bulan. Pekerjaan sebagai Kepala Dusun dilakukan pada saat tidak melaut di pagi hari dan sebagai pemilik perahu lampu di saat nelayan pemilik soma pajeko mengajak untuk melaut membantu operasi penangkapan. Semuanya mereka lakukan dan berusaha memenuhi kebutuhan hidup keluarganya tanpa memperhatikan pendidikan anak - anak mereka.

\section{Pengaruh Pengeluaran Terhadap Tingkat Pendidikan Anak}

Berdasarkan hasil penelitian dapat dilihat pengeluaran kurang dari $\mathrm{Rp}$ 1.000 .000 berjumlah 2 orang (8\%), selanjutnya pengeluaran responden $\mathrm{Rp}$ 1.000 .000 - Rp 3.000.000 berjumlah 15 orang $(60 \%)$, dan yang terakhir pengeluaran responden lebih dari $\mathrm{Rp}$ 3.000 .000 berjumlah 8 orang (32\%).

Besar kecilnya pengeluaran disebabkan besarnya ongkos atau harga yang harus dibayar mencakup biaya untuk makanan, pakaian, kesehatan, perumahan, listrik, transportasi dan lainnya sehingga biaya untuk pendidikan anak akan ikut dipengaruhi pula. Ada nelayan yang mengeluarkan biaya lebih dari Rp. 3.000 .000 per bulan karena menyekolahkan anak sampai Perguruan Tinggi. Hal ini terjadi pada nelayan yang memiliki pekerjaan sampingan sebagai nelayan perahu lampu dan ada yang berstatus Kepala Dusun.

\section{KESIMPULAN}

Kondisi Sosial Ekonomi Keluarga Nelayan, dilihat dari mayoritas umur responden berada di usia produktif, agamanya baik karena seluruh responden pemeluk agama yang taat, pendidikanya rendah karena mayoritas tidak tamat SD, tanggungan keluarga nelayan rata - rata memiliki anggota keluarga $(1-5)$ jiwa per kepala keluarga. Sedangkan dilihat dari perumahan belum memadai karena $44 \%$ dari responden masih memiliki rumah yang terbuat dari papan/triplex. $76 \%$ keluarga nelayan di Desa Bulawan Induk semuanya memiliki modal sendiri, tingkat pendapatan responden rata - rata ada pada kisaran $44 \%$ memiliki pendapatan Rp 2.000.000 - Rp 3.000.000 per bulan. Sedangkan mayoritas $32 \%$ tingkat pengeluaran responden berkisar antara Rp 1.000.000 - Rp 3.000.000. Besar kecilnya tingkat pengeluaran disebabkan besarnya ongkos atau harga yang harus di bayar mencangkup seluruh biaya untuk biaya makanan, pakaian, pendidikan, perumahan, listrik, transportasi, dan lainnya, sehingga pendidikan anak masi terabaikan. 
Menurut hasil penelitian di atas dapat dikatakan bahwa Kondisi Sosial Ekonomi Keluarga Nelayan Di Desa Bulawan Induk ternyata sangat berpengaruh terhadap tingkat pendidikan anak.

\section{DAFTAR PUSTAKA}

Abdulsyani. 1994. Sosiologi Sistematika, Teori dan Terapan. Jakarta: Bumi Aksara.

Abdurahman, Fathoni.2006. Metodologi Penelitiandan Teknik Penyusunan Skripsi. Jakarta: PT. Rineka Cipta.

Arikunto, Suharsimi. 2010. Prosedur Penelitian Suatu Pendekatan Praktek. Jakarta: Rineka Cipta.

Bambang Swasto Sunuharjo. 2009. Kemiskinan dan Kebutuhan Pokok. Jakarta: Yayasan IImu Sosial.

Departemen Kelautan dan Perikanan Republik Indonesia. 2004. Undang-Undang Perikanan. Jakarta: Departemen Kelautan dan Perikanan Republik Indonesia.

Dinas Perikanan Peraturan Bupati Bolaang Mongondow Timur. 2017. Tentang Susunan Organisasi dan Tata Kerja Dinas Perikanan Tipe A Kabupaten Bolaang Mongondow Timur.

DwiSiswoyo. 2011. IlmuPendidikan. Yogyakarta: UNY Press.

Eko Wahyu Tyas, D. 2008. Penerapan Metode Association Rules Menggunakan Algoritma Apriori Untuk Analisa Pola Data Hasil Tangkapan Ikan.

Fathoni, A. 2006. Metodologi Penelitian dan Teknik Penyusunan Skripsi. Jakarta: PT. Rineka Cipta.

Gilarso, T. 2004. Pengantan Ekonomi Makro. Yogyakarta: Penerbit Kanisius.

Gilarso, T. 2008. Pengantar IImu Ekonomi Mikro. Yogyakarta: Kanisius, Edisi 5.

Kusnadi. 2009. Keberdayaan Nelayan dan Dinamika Ekonomi Pesisir. Yogyakarta: Ar-Ruzz Media.2003. Akar Kemiskinan Nelayan.Yogyakarta: LKiS.

Kusnadi. 2009. Keberdayaan Nelayan dan Dinamika Ekonomi Pesisir. Yogyakarta: Ar-Ruzz Media.

Muhamad, H. 2017. Metodologi dan Teknik Penulisan Skripsi, Tesis dan Disertasi. Diandra Kreatif.
Mulyadi. 2007. Ekonomi Kelautan. Jakarta: PT. Raja Grafindo Persada.

Mulyanto Sumardi. 2004. Kemiskinan dan Kebutuhan Pokok. Jakarta: Rajawali.

Nasution. 2004. Sosiologi Pendidikan. Bandung: Jemmars.

Nasution. 2005. Sosiologi Pendidikan. Bandung: Jemmars.

Ninik, S dan Muflikhati, I. (2006). Persepsi Nelayan tentang Pendidikan Formal di Kecamatan Rembang, Kabupaten Rembang Provinsi Jawa Tengah. Jurnal Buletin Ekonomi Perikanan, VI, (3), 40-49.

Nawawi, Hadari. 2015. Metode Penelitian Bidang Sosial. Yogyakarta: Gajah Mada University Press.

Soerjono Soekanto. 2007. Sosiologi Suatu Pengantar. Jakarta: Rajawali Press.

Soediyono Reksoprayitno. 2009. Ekonomi Makro. Badan Penerbit Fakultas Ekonomi (BPFE): UGM.

Sugiyono. 2014. Metode Penelitian Kuantitatif, Kualitatif dan R\&D. Bandung: Penerbit Alfabeta.

Sumintarsih, dkk. 2005. Kearifan Lokal di Lingkungan Masyarakat Madura. Yogyakarta: Kemenbudpar.

Supardi, M. D. 2006.Metode Penelitian.Mataram: Yayasan Cerdas Press.

Suroyyo, A.N. 2017. Analisis Ekonomi Rumah Tangga Nelayan Pada Alat Tangkap Gill Net di PPP Morodemak, Kabupaten Demak. Journal of Fisheries Resources Utilization Management and Technology Volume 6, Nomor 4, Tahun 2017, HIm 30-39 Online di: http://www.ejournal-

s1.undip.ac.id/index.php/jfrumt.

Tarigan, S. E. 2009. Analisis Pekerjaan Alternatif Nelayan Kecamatan Talawi Kabupaten Batu Bara (Studi Kasus: Desa Majid Lama Kecamatan Talawi Kabupaten Batu Bara). Skripsi.Departemen Agribisnis Fakultas Pertanian Universitas Sumatra Utara Medan.

Undang-Undang Nomor 20 Tahun 2003. Tentang Sistem Pendidikan Nasional.

Wakhid, Abdul. 2008. Pendidikan Versus Kemiskinan. (online). Jurnal Nadwa, Volume 2, No 1, Mei 2008. HIm. 100. Diakses 9 Januari 2018 (isjd.pdii.lipi.go.id/admin/jurnal/210883105.pdf) 